\title{
PENENTANGAN LAKI-LAKI MINANGKABAU TERHADAP BUDAYA MINANGKABAU DALAM NOVEL HAMKA
}

\author{
Jasril \\ Program Studi Pendidikan Bahasa dan Sastra Indonesia \\ STKIP YDB Lubuk Alung, Sumatera Barat \\ Pos-el: jasrilpiliang2000@gmail.com
}

\begin{abstract}
Abstrak
Minangkabau menganut sistem kekerabatan matrialineal yang menempatkan laki-laki pada posisi unik, yaitu tidak memiliki hak warisan atas pusaka turunan dan tidak mewariskan suku kepada anaknya. Dampak perlakuan adat tersebut tidak terlihat secara kasat mata, namun bila dicermati, ditemukan penentangan yang dilakukan oleh laki-laki Minangkabau melalui sastra tradisi seperti pantun, kaba, dan nyanyian. Penelitian ini mencoba melihat sejauh mana novel karya Hamka merefleksikan penentangan laki-laki Minangkabau terhadap budayanya. Pandangan ini berangkat dari asumsi bahwa karya sastra modern (novel) merupakan kelanjutan dari sastra tradisi. Teori yang mendasari kajian ini adalah teori sosiologi sastra dengan menggunakan pendekatan mimesis. Jenis penelitian ini adalah kualitatif deskripstif. Pengumpulan dan penganalisisan data dilakukan secara bersamaan dengan teknik baca-catat-analisis, menggunakan metode content analysis dan metode pembacaan heuristik dan hermeneutik. Hasil penelitian dan pembahasan menunjukan bahwa novel karya Hamka sarat dengan pencerminan sosial budaya Minangkabau. Laki-laki dalam budaya Minangkabau berada pada posisi yang tidak menguntungkan, memiliki kekuatan dan kekuasaan, tetapi tidak memiliki hak atas harta pusaka. Oleh sebab itu, laki-laki melakukan penentangan dalam bentuk menolak pulang ke Minangkabau dan meninggalkan Minangkabau. Penentangan yang dilakukan berdasarkan motif agama Islam yang tidak membedakan laki-laki dengan perempuan baik dalam pembagian warisan maupun dalam pernikahan.
\end{abstract}

Kata Kunci: penentangan, laki-laki Minangkabau, budaya Minangkabau, novel Hamka

\begin{abstract}
Minangkabau submit matrialineal system that put the men in an unique position which they does not have right of legacy for heritage and they does not bequeath ethnic group to their children. The impact of tradition treatment could not be seen in plain view, however if it is careful, it found the resistance that done by Minangkabau's men through literature tradition such as pantun, kaba and a song. This article tried to see how far novel created by Hamka reflected the resistance of Minangkabau's men toward their culture. This point of view appeared from an assumption that modern literature (novel) is continuance from literature tradition. The basic of theory in this study is literature sociology theory with using mimesis approach. Kind of this research was descriptive qualitative. Collecting and analyzing of data did simultaneously with read-note-analysis technique, using content analysis method and heuristic and hermeneutic method. Result of the research and discussion showed that novel by Hamka many showing socio culture of Minangkabau. The men in Minangkabau tradition located in unlucky position, they had a power and legitimacy, but they did not have right of legacy for heritage. Therefore, the men did a resistance such as they won't come back to Minangkabau and left Minangkabau. The resistance that conducted based on Islam motive which it is not comparing the men and the women in distribution of legacy although in wedding.
\end{abstract}

Key words: resistance, Minangkabau's men, culture of Minangkabau, Hamkas' novel 


\section{PENDAHULUAN}

Sudah sejak lama budaya Minangkabau menimbulkan keingintahuan banyak orang, khususnya peneliti dan pengamat yang berasal dari berbagai disiplin ilmu, termasuk sastra (Arifin, 2009:150). Kemenarikan itu disebabkan karena masyarakat Minangkabau termasuk masyarakat yang dualism. Di satu sisi, Minangkabau sangat menjunjung tinggi agama Islam yang terungkap dalam falsafah, "Adat basandi syarak; Syarak basandi kitabullah", 'Adat bersendikan syarak atau agama; Syarak atau agama bersendikan kitab Allah (Alquran)'. Sementara di sisi lain, masyarakat Minangkabau juga menjunjung adat yang dalam praktik pelaksanaanya banyak bertentangan dengan agama Islam, misalnya dapat dilihat dari konsep perkawinan dan pembagian harta warisan. Gambaran dualisme praktik sosial ini menyebabkan orang menganggap Minangkabau adalah masyarakat yang berbudaya "ambigu" menurut istilah Sairin (2002), atau dengan menurut istilah Azwar (2001) disebutkan sebagai masyarakat yang "secara politik ada persaingan antar kelompok".

Dualisme budaya Minangkabau telah menguntungkan perempuan yang ditandai dengan semakin kuatnya posisi perempuan dalam adat Minangkabau, sedangkan posisi lakilaki semakin lemah. Posisi laki-laki yang lemah itu memang tidak memunculkan protes secara terbuka, namun jika diteliti secara cermat, protes itu muncul dalam bentuk nuansa melankolis yang mewakili perasaan laki-laki sangat kental dalam sastra tradisi Minangkabau, seperti pantun, kaba, dan nyanyian. Nuansa melankolis itu lebih merupakan dendam laten daripada protes yang disampaikan secara terbuka. Dampak dari dendam laten itu berwujud menjadi perilaku merantau yang dilakukan oleh laki-laki Minangkabau yang pada dasarnya adalah pencarian harga diri. Asumsinya, jika tidak ada yang dimiliki di kampung halaman sendiri, di luar tanah Minangkabau pasti ada, sekurang-kurangnya pergi belajar dalam arti yang luas untuk mendapatkan martabat sebagai lelaki. Bentuk kegelisahan itu, terungkap dalam pantun "merantau" berikut ini.

Karatau madang di hulu

Berbuah berbunga belum

Merantau bujang dahulu

Di rumah berguna belum

Wujud parktis dari pelaksanaan pantun di atas adalah perilaku merantau laki-laki Minangkabau sejak usia muda. Merantau sejak usia muda pada dasarnya adalah belajar menjadi "orang". Entah akan menjadi pemilik warung padang, meskipun pada awalnya bekerja sebagai pencuci piring. Mungkin juga akan menjadi pedagang yang sukses di pasar kota rantau, meski pada awalnya menjadi pengecer di kaki lima. Barangkali juga akan memiliki usaha transportasi, meski pada awalnya bekerja sebagai kondektur bus kota. Boleh jadi menjadi dai kondang meski pada awalnya menumpang tidur di surau atau masjid karena tidak punya tempat tinggal di rantau. Kemungkinan juga akan menjadi ilmuwan karena belajar di perguruan tinggi.

Berangkat dari pandangan di atas, terlihat bahwa sastra tradisi (pantun, kaba, dan nyanyian) merupakan alat bagi laki-laki Minangkabau untuk menyampaikan protes mereka terhadap budaya Minangkabau. Hal ini barangkali sesuai dengan fungsi sastra tradisi (kaba) bagi masyarakat Minangkabau yang tidak hanya sebagai hiburan semata, tetapi juga pembawa nilai-nilai kehidupan (Jasril, 2015:41). Oleh sebab itu, penentangan laki-laki dalam budaya Minangkabau yang menganut sistem matrilineal menarik untuk diteliti melalui karya sastra, baik sastra tradisi maupun sastra modern. Dengan demikian, dapat ditarik benang merah penentangan yang dilakukan oleh lakilaki Minangkabau sejak masa lampau hingga masa kini, dapat dilihat melalui penelitian karya sastra naratif (novel) yang hidup di daerah ini dengan asumsi bahwa novel Indonesia modern berlatar dan ditulis oleh pengarang 
asal Minangkabau, merupakan kelanjutan dari sastra tradisi, seperti pantun, kaba, dan nyanyian (Thahar, 2002:28).

Hamka dibesarkan dan dididik dalam lingkungan pendidikan surau dan berkiprah di rantau seperti Medan dan Jakarta. Pendidikan yang dijalaninya sangat memengaruhi pikiranpikirannya dalam memandang kehidupan budayanya. Sebagai seorang etnis Minangkabau yang hidup dirantau, tentu dia sudah berintegrasi dengan bermacam-macam budaya. Asimilasi budaya itu juga sangat memengaruhi pikirannya dalam memandang budaya Minangkabau. Dalam hal ini, Hamka memandang budaya lain kemudian membandingkan dengan budayanya sendiri (budaya Minang). Melalui proses perbandingan ini, Hamka melihat kelemahan dan kekuatan budayanya sendiri. Dengan demikian, munculah keinginan Hamka untuk memperbaiki adatnya sendiri agar menjadi lebih baik.

Hamka, disamping sebagai ulama, dia juga populer sebagai sastrawan. Sebagai seorang sastawan, banyak novel yang lahir dari buah tintanya, seperti Novel Merantau ke Deli (1959); Dijemput Mamaknya (1962); Tenggelamnya Kapal Van Der Wijck (1976); Di bawah Lindungan $K a ' b a h$ (1979). Novel-novel itu sampai sekarang masih dicari dan diperbincangkan orang. Sebagai pengarang yang berasal dari Minangkabau, sudah tentu novel-novel yang ditulisnya mengangkat persoalan-persolan Minangkabau. Hal ini sesuai dengan apa yang dikemukakan Darma (2007:25), proses kreatif tidak bisa terhindar dari tradisi, betapapun orisinalnya seorang sastrawan sewaktu menulis, mereka selalu berpijak pada tradisi mereka sebelumnya. Bila karya sastra merupakan cerminan masyarakat tempat sastra itu lahir, penentangan lakilaki Minangkabau terhadap budaya Minangkabau tentu saja terefleksi di dalamnya.

Bertolak dari pemikiran itu, jelas bahwa di dalam karya sastra tercermin ideologi sebagai fakta kultural. Hal ini sejalan dengan pendapat Hoggart (1975) yang mengatakan bahwa karya sastra selalu disinari oleh ideologi dan nilai-nilai budaya yang diterapkan. Oleh karena itu, yang dilakukan pengarang di dalam karyanya adalah masalah-masalah yang berhubungan dengan kehidupan individu-individu dalam struktur masyarakatnya. Kemudian, patut pula diingat bahwa pengarang adalah produk dari zaman dan lingkungannya. Oleh karena itu, sudah barang tentu banyak-sedikit pola berpikirnya juga dipengaruhi oleh hal itu. Ide yang terdapat dalam pikiran pengarang itulah yang kemudian ditransformasikan melalui tokohtokoh cerita. Dengan demikian, sastra berarti pengucapan pengalaman kultural sebagai ekspresi budaya.

Penelitian ini bertujuan mendeskripsikan: (1) posisi laki-laki dalam budaya Minangkabau, (2) bentuk penentangan laki-laki Minangkabau terhadap budaya Minangkabau, (3) motif penentangan laki-laki Minangkabau terhadap budaya Minangkabau. Diharapkan dengan terwujudnya tujuan di atas, temuan penelitian ini akan bermanfaat, baik secara teoretis maupun praktis. Secara teoretis, temuan penelitian ini dapat memberikan sumbangan positif dalam membangun konsep teoretis pengkajian sastra Indonesia. Sementara itu, secara praktis, temuan kajian ini berguna bagi pihak yang berkompeten untuk mengarahkan negara bangsa (nation state) ini menjadi masyarakat sipil (civil society) yang demokratis, humanis, beradab yang teraplikasi pada sikap (1) cinta semua orang; (2) toleransi antar sesama; (3) menjalin persahabatan tanpa memandang status sosial; (4) membangun kesetaraan antarmanusia; (5) menyediakan alternatif untuk pembelajaran sastra, khususnya novel, baik di sekolahsekolah maupun diperguruan tinggi.

\section{TEORI DAN METODE}

Karya sastra merupakan alat untuk menyampaikan visi, misi, ideologi, dan opini pengarang terhadap sesuatu yang dilihat, dirasakan, diamati, dan dipikirkannya pada masanya. Sebagai suatu media yang terbentuk dari 
hasil pekerjaan kreatif, objeknya adalah manusia dengan segala persoalan kemanusiaannya. Menurut Damono (2002:1), karya sastra selalu menampilkan gambaran kehidupan, sedangkan kehidupan itu sendiri adalah suatu kenyataan sosial. Oleh karena itu, yang dilakukan pengarang di dalam karyanya adalah mengangkat masalah-masalah yang berhubungan dengan kehidupan individu-individu dalam struktur masyarakatnya. Kemudian, patut pula diingat bahwa pengarang adalah produk dari zaman dan lingkungannya (Hudson, 1955:4). Sudah jelas banyak-sedikitnya pola berpikirnya dipengaruhi oleh kondisi sosial masyarakatnya. Ide yang terdapat dalam pikirannya itulah yang yang ditransformasikannya melalui tokoh-tokoh cerita. Dengan demikian, segala aspek kehidupan manusia dengan budayanya terdapat dalam sastra. Jadi, penentangan laki-laki Minangkabau terhadap budaya Minangkabau merupakan pencerminan kebudayaan masyarakat Minangkabau, sebab sastra merupakan pengucapan pengalaman kultural sebagai penggambaran ekspresi budaya.

Ideologi masyarakat Minangkabau selalu didasarkan pada "Adat basandi syarak; Syarak basandi kitabullah", 'Adat bersendikan syarak atau agama; Syarak atau agama bersendikan kitab Allah (Alquran)'. Di dalam filosofi ini terkandung dua ideologi yang pada hakikatnya saling bertentangan, tetapi di dalam kehidupan masyarakat Minangkabau, kedua ideologi ini saling melengkapi antara satu dengan yang lainnya. Begitu ketatnya ajaran ideologi itu dalam kehidupan bermasyarakat Minangkabau, hampir setiap aspek kehidupan masyarakat berpatokan pada ideologi tersebut. Misalnya ideologi adat, hampir semua aspek kehidupan, seperti sistem perkawinan, pembagian harta warisan, pengakatan pemimpin adat, kedudukan, dan fungsi penghulu, kedudukan dan fungsi Bundo Kanduang, konsep harga diri, konsep budi dan lain sebagainya selalu didasari oleh ideologi adat. Sebaliknya, ideologi syarak (agama Islam) juga begitu kental mewarnai kehidupan masyarakat Minangkabau, seperti terlihat hampir tidak ada nagari di Minangkabau yang tidak punya masjid.

Karya sastra sebagai karya kreatif imajinatif menampilkan berbagai fenomena kehidupan. Fenomena ini merupakan peristiwa yang terjadi pada masyarakat atau refleksi dari kehidupan nyata. Pengarang mengambil material ceritanya dari peristiwa-peristiwa yang terjadi dalam kehidupan melalui proses melihat, mendengar, membaca, bahkan mengalaminya sendiri. Peristiwa tersebut diolah, dibumbui, dan dipoles dengan berbagai imajinasi sehingga terbentuklah sebuah cerita. Pengolahan inilah yang mengahasilkan cerita sebagai dunia baru atau dunia simbol, dan untuk memahaminya diperlukan intrerpretasi. Meskipun cerita (karya sastra) hanyalah dunia simbol, setidaknya dari dunia simbol ini dapat dilihat ideologi yang dikandungnya atau dari kata ke ideologi.

Untuk mengungkapkan penentangan lakilaki Minangkabau terhadap budaya Minangkabau yang terefleksi dalam novel Hamka, digunakan gabungan teori interpretasi teks dan sosiologi sastra. Di dalam penelitian ini, akan diinterpretasikan dan dimaknai secara spesifik mengenai penentangan laki-laki terhadap budaya Minangkabau dalam novel Hamka. Menurut Ricoeur (dalam Kleden 1997:42), teks (dalam hal ini novel karya Hamka) dapat digunakan sebagai paradigma untuk memahami dan menjelaskan tindakan dan pengalaman manusia. Dengan menggunakan teks sebagai paradigma, pada hakikatnya Ricoeur mengatakan bahwa tujuan terpenting dari penafsiran teks bukanlah sekadar memahami makna teks itu sendiri, melainkan untuk memahami eksistensi manusia dan dunianya. Ricoeur dalam Valdes (1997:6) berpendapat bahwa arti dan makna sebuah teks sastra diperoleh melalui upaya pencarian dalam teks berdasarkan bentuk, sejarah, pengalaman pembaca dan self reflection dari prilaku interpretasi itu untuk mengeksplisitasikan jenis being-in-the world (dasain) yang terungkap dalam dan melalui teks. 
Pendekatan sosiologi sastra menganggap bahwa karya sastra milik masyarakat. Karya sastra berasal dari masyarakat dan kembali kepada masyarakat. Menurut Ratna (2004:60), dasar hubungan filosofis pendekatan sosiologis adalah adanya hubungan yang hakiki antara karya sastra dengan masyarakat. Hubungan tersebut terbentuk dari (a) karya sastra dihasilkan oleh pengarang, (b) pengarang adalah bagian dari anggota masyarakat, (c) pengarang memanfaatkan kekayaan yang ada dalam masyarakat sebagai material karya sastra, dan (d) hasil karya sastra dimanfaatkan kembali oleh masyarakat. Hal ini barangkali yang menyebabkan Ratna (2004:237) mengatakan bahwa karya sastra lebih jelas mewakili zamannya. Pendekatan sosiologi bertolak dari asumsi bahwa sastra merupakan cerminan kehidupan masyarakat. Melalui karya sastra, seorang pengarang mengungkapkan masalah kehidupan yang pengarang sendiri ikut di dalamnya. Karya sastra menerima pengaruh dari masyarakat dan sekaligus mampu memberi pengaruh terhadap masyarakat, bahkan seringkali masyarakat sangat menentukan nilai karya sastra yang hidup di suatu zaman. Di sisi lain, sastrawan itu sendiri yang merupakan anggota masyarakat tidak dapat mengelak dari adanya pengaruh yang diterima dari lingkungan yang membesarkannya dan sekaligus membentuknya.

Kajian ini menggunakan pendekatan kualitatif deskriptif. Pengumpulan dan penganalisisan data dilakukan secara bersamaan dengan teknik baca-catat-analisis, menggunakan metode content analysis serta metode pembacaan heuristik dan hermeneutik untuk menggali isi, pesan-pesan yang terkandung pada objek penelitian, dan memberi makna pada pesan yang terkandung di dalamnya untuk menggambarkan gejala sosial yang terjadi. Datanya berupa kata-kata, kalimat, dan wacana yang mengandung penentangan laki-laki Minangkabau terhadap budaya Minangkabau. Sumber data adalah novel karya Hamka yang diwakili oleh Novel Tenggelamnya Kapal Van der
Wijck (2001) dan Di Bawah Lindungan Ka'bah (2010). Pengumpulan data dan analisis data dilakukan secara bersamaan dengan kegiatan membaca novel secara berulang-ulang, mengiventarisasi, mengidentifikasi, mengklasifikasi, menginterpretasi, membahas, dan menyimpulkan.

\section{HASIL DAN PEMBAHASAN}

Novel Tenggelamnya Kapal Van der Wijck karya Hamka yang dijadikan objek penelitian ini merupakan cetakan ke-25 tahun 2001. Novel ini bertemakan konflik diskriminasi manusia karena latar belakang sosial budaya yang muncul ke permukaaan karena pertikaian antara satu tokoh dengan tokoh yang lain. Datuk merasa lebih beradat dan lebih tinggi dari Zainuddin yang merupakan orang Mengkasar anak dari Pandeka Sutan, orang Batipuh. Pandeka Sutan merupakan orang yang terusir dari kampung halaman karena membunuh mamaknya Datuk Mantari Labih yang memperlakukannya dengan sewenang-wenang. Selanjutnya, Novel Di Bawah Lindungan Ka'bah karya Hamka yang dijadikan objek penelitian ini merupakan cetakan ke-31 tahun 2010. Novel ini bertemakan tentang cinta yang tak sampai karena perbedaan status sosial yang menghalangi Zaenab dan Hamid hidup bersama. Hamid adalah seorang pemuda miskin yang tinggal bersama ibunya karena ayahnya telah meninggal semasa Hamid kecil. Sementara, Zaenab anak seorang saudagar kaya. Orang tuanya memilihkan keponakan ayahnya sebagai pasangan hidup untuk Zaenab agar harta kekayaannya tetap terjaga, dan hubungan keluarga tetap terjalin erat.

\section{Posisi Laki-laki Di Minangkabau dalam Novel Hamka}

Minangkabau menganut sistem kekerabatan matrilineal, yaitu alur keturunan berdasarkan garis keturunan ibu. Konsekuensi dari sistem matrilineal menempatkan perempuan pada posisi yang tinggi dibandingkan dengan laki- 
laki. Keistimewaan yang dimiliki oleh perempuan Minangkabau adalah posisinya sebagai Bundo Kanduang. Bundo Kanduang memainkan peranan dalam menentukan keberhasilan pelaksanaan keputusan-keputusan yang dibuat oleh kaum laki-laki dalam posisi mereka sebagai mamak (paman atau saudara dari pihak ibu), dan penghulu (kepala suku) (Arifin, 2012: 31). Posisi istimewa yang dimiliki perempuan juga menjadikannya sebagai pilar utama rumah atau dengan istilah Limpapeh Rumah nan Gadang. Sebuah julukan yang menunjukan kekuasaan perempuan terhadap rumah adat di Minangakabau. Puncak dari keistimewaan yang dimiliki perempuan adalah menempatkannya sebagai pewaris harta pusaka dan penerus keturunan. Garis keturunan dirujuk kepada ibu yang dikenal dengan Samande (se-ibu).

Sementara, laki-laki (ayah dalam adat Minangkabau disebut dengan nama Sumando (ipar)) diperlakukan sebagai tamu dalam keluarga istrinya. Menurut adat Minangkabau, seorang sumando adalah orang luar (orang asing) dalam kaum istrinya yang ditunjukkan dengan pepatah "bak abu di ateh tunggua", 'seperti abu di atas tunggul'. Pepatah ini mengisyaratkan bahwa laki-laki Minangkabau di rumah istrinya diposisikan sebagai orang asing karena "dititipkan" di rumah perempuan (istrinya) sehingga setiap saat bisa saja "diusir seperti abu yang rentan terbang ditiup angin kencang" (Arifin, 2012:34). Oleh sebab itu, lakilaki (sumando) dipandang tamu dan diperlakukan sebagai tamu dalam keluarga istrinya, tujuan utamanya adalah untuk memberikan keturunan. Sementara, dalam garis keturunan ibunya, laki-laki berfungsi sebagai anggota keluarga. Dia menjadi wali dari garis-keturunannya dan berkewajiban melindungi harta benda garis keturunan ibunya, meskipun harus menahan dirinya dari menikmati hasil tanah kaumnya karena dia tidak mendapatkan bagian apa-apa. Tidak pula dia diberi tempat di rumah orangtuanya karena semua bilik (kamar) hanya diperuntukkan bagi saudara perem- puannya untuk menerima suami-suami mereka. pencerminan kondisi laki-laki di Minangkabau dapat dilihat dalam kutipan berikut.

\section{...Menurut adat Minangkabau, amatlah ma- langnya seorang laki-laki jika tidak mem- punyai saudara perempuan, yang akan menjagai harta benda, sawah yang ber- jenjang, bandar buatan, lumbung berpe- reng, rumah nan gadang (Hamka 2009, hlm.5).}

Berdasarkan kutipan di atas, jelas bahwa laki-laki tidak mempunyai kuasa untuk memakai harta pusaka. Bila terpaksa harus mengolah tanah dari garis keturunan ibunya. Seorang anak laki-laki haruslah sebagai seorang penyedua (pekerja bagi hasil), dia menerima hanya sebagian dari hasil, sedangkan bagian yang lain diperuntukkan kepada anggota garisketurunan wanita yang sebenarnya menjadi pemilik tanah tersebut. Dalam keluarga, posisi laki-laki hanya berfungsi sebagai peripheral, sebagai pelindung keluarga, termasuk dalam hal warta warisan keluarga. Oleh karena itu, seorang laki-laki bila sudah menikah di Minangkabau dianggap sebagai "mamak" dan berfungsi sebagai protektoral dan seremonial untuk berhadapan dengan dunia luar. Maksudnya adalah apa yang disampaikan kepada dunia luar adalah suara keluarga yang sebelumnya telah dimufakati dan diputuskan Bundo Kanduang. Dengan sistem matrilineal itu, budaya Minangkabau memberikan kesempatan kepada perempuan untuk memiliki kekuatan dan kekuasaan secara komunal.

\section{Bentuk Penentangan Laki-laki Minangkabau Terhadap Budaya Minangkabau dalam Novel Hamka}

Dalam Novel Tenggelamnya Kapal Van Der Wijck diceritakan bahwa setelah bebas dari hukuman yang dijalaninya selama lima belas tahun, Pandeka Sutan memilih menetap di Mengkasar daripada pulang ke Minangkabau. Perkenalan Pandeka Sutan dengan Mengkasar berawal ketika dia menjalani proses hukuman 
pernah di bawah ke Mengkasar sebagai orang rantai. Meskipun batinnya sangat ingin pulang ke tanah tumpah darahnya, namun ditahanya, dilulurnya air matanya. Biarlah negeri Padang "dihitamkan" untuk selama-lamanya. Pandeka Sutan menyadari bahwa pulang pun dia tidak akan berarti di kampungnya karena tidak memiliki saudara perempuan.

Saudara yang kandung tak ada, terutama saudara perempuan. Ibu tempat perlindungan orang laki-laki di negeri yang berbangsa kepada ibu itu telah lama pula meninggal. Meskipun dia akan diterima orang dengan manis, yang terkandung di dalam hati mereka tentu labih pahit. Sebab dia tak beruang, kepulangannya menimbulkan cemburu hati keluarga-keluarga dalam persukuan,

Kalau tidak ranggas di Tanjung,

Cumanak ampaian kain.

Kalau tidak emas dikandung,

Dunsanak jadi rang lain.

(Hamka 2009, hlm. 8-9)

Sikap Pandeka Sutan yang lebih memilih menetap di Mengkasar daripada Minangkabau merupakan bentuk penetangan terhadap budaya Minangkabau yang "meminggirkan" laki-laki bila tidak memiliki saudara perempuan. Laki-laki yang tidak memiliki saudara perempuan dalam adat Minangkabau rentan terhadap perbuatan sewenang-wenang. Hal itu disebabkan kedudukan anak laki-laki di Minangkabau tidak terlalu dipedulikan dalam kerangka rumah gadang bila tidak mempunyai saudara perempuan. Menurut ketentuan adat, seorang anak laki-laki mempunyai kedudukan yang tidak jelas terutama bagi mereka yang belum kawin (Amir, 1997:86). Jika kita telusuri lebih jauh lagi dalam Tenggelamnya Kapal Van Der Wijck, anak laki-laki bukan saja tidak dipedulikan, tetapi juga dijauhkan dari rumah gadang. Oleh sebab itu, pilihan Pandeka Sutan untuk tidak tidak pulang ke kampung setelah habis masa hukumannya merupakan pilihan yang bijak.
Penentangan Pandeka Sutan terhadap budaya Minangkabau sudah dimulai sejak ia berkeinginan menikah. Penentangan ini pada awalnya muncul karena disebabkan oleh kesewenang-wenangan mamaknya, Datuk Mantari Labih. Pandeka Sutan melihat bahwa Datuk Mantari Labih pernah menggadaikan harta pusaka kaumnya untuk mengawinkan anaknya. Bahkan, Pandeka Sutan juga melihat beberapa tumpak sawah digarap oleh istri mamaknya itu. Oleh sebab itu, ketika berkeinginan menikah Pandeka Sutan juga berniat untuk menggadaikan sepetak sawah untuk keperluan penyelenggaraan pernikahannya. Keinginan itu, disampaikan kepada mamaknya, Datuk Mantari Labih. Namun, ditolak oleh Datuk Mantari Labih. Bahkan, Datuk Mantari Labih memarahi Pandeka Sutan di rumah gadang, di depan banyak orang, seperti yang terlihat pada kutipan berikut.

"Daripada engkau menghabiskan harta
itu, lebih baik engkau hilang dari negeri,
saya lebih suka."
"Kalau akan berbini mesti lebih dahulu
menghabiskan harta tua, tentu habis
segenap sawah di Minangkabau ini. inilah
anak muda yang tidak tahu malu, selau
hendak menggadaikan, benak pengagun."
(Hamka, 2009:6).

Mendengar perkataan mamaknya, Pandeka Sutan merasa dipermalukan di depan orang banyak, dan sikap perlawananya pun muncul. Kemudian Pandeka Sutan mengatakan mamaknya itu zalim, sebab dia menggadaikan harta pusaka bukan untuk kaumnya melainkan untuk anak dan istrinya seperti yang terlihat dalam kutipan berikut.
"Mamak sendiri juga pernah menggadai- kan, bukan untuk mengawinkan keme- nakan, tetapi untuk mengawinkan anak mamak sendiri. Berapa tumpak sawah yang dikerjakan oleh istri mamak, kami tidak mendapat sebagian." (Hamka, 2009:6). 
Dalam adat Minangkabau, mamak adalah saudara laki-laki Ibu, sedangkan kemenakan adalah anak saudara perempuan. Dalam penataan kehidupan sepesukuan, mamak adalah pemimpin terhadap kemenakan yang satu suku dengannya. Penunggalan kepemimpinan dalam satu pesukuan dipilih salah seorang mamak yang diangkat menjadi penghulu dengan gelar "datuk". Hubungan antara mamak dengan kemenakan diatur seperti pepatah berikut ini.

\section{Kemenakan beraja ke mamak}

Mamak beraja kepada penghulu

Penghulu beraja kepada musyawarah

Musyawarah beraja kepada alur dan patut.

Berdasarkan ketentuan yang terdapat dalam pepatah di atas, jelas bahwa kemenakan dipimpin oleh mamak. Buruk baiknya seorang kemenakan ditentukan oleh kepemimpinan mamaknya, dalam bentuk yang lebih luas oleh kepemimpinan penghulunya (Asri, 2011:250). Dalam Tenggelamnya Kapal Van Der Wijck, sikap kepemimpinan yang buruk dari Datuk Mantari Labih memicu penentangan yang dilakukan oleh Pandeka Sutan. Dia melihat Datuk Mantari Labih tidak memberikan contoh yang baik kepadanya dalam hal pengelolaan harta pusaka. Datuk Mantari Labih menggadaikan harta pusaka untuk kepentingan anak dan istrinya, sementara dia sendiri yang merupakan pewaris harta itu dilarang menggadaikannya. Sikap Pandeka Sutan ini merupakan sikap yang diperbolehkan, sebab oleh adat ada kemungkinan mamak tidak harus ditaati kemenakannya bila memimpin secara tidak bijaksana dan hanya mementingkan diri sendiri. Mamak yang dimaksud adalah mamak yang dinukilkan dalam pepatah berikut ini.

Raja adil, raja disembah

Raja lalim, raja disanggah

Laki-laki sebagai mamak di Minangkabau diharuskan menjadi sosok yang dwifungsi, yaitu di satu sisi ia adalah mamak oleh kemenakannya, sedangkan di sisi lain, dia adalah ayah oleh anak-anaknya (Asri, 2011:250). Oleh sebab itu, seorang laki-laki Minangkabau harus memerhatikan dan membimbing anak dan kemenakannya tanpa harus memihak kepada anak atau kemenakan saja. Anak dan kemenakan bagi seorang laki-laki Minangkabau ditempatkan dalam posisi: anak dipangku kemenakan dibimbing. Tidak dilarang seorang lakilaki mengutamakan anaknya, asalkan tidak mengabaikan kemenakannya. Namun tugas ini belum mampu diemban dengan baik oleh Datuk Mantari Labih sehingga memunculkan perlawanan bagi kemenakannya, Pandeka Sutan.

Budaya Minangkabau tidak hanya ditentang oleh Pandeka Sutan (Tenggelamnya Kapal Van Der Wijck), tetapi juga ditentang oleh Hamid (Di Bawah Lindungan Ka'bah). Cara yang ditempuh oleh Hamid, yaitu meninggalkan Minangkabau. Hamid meninggalkan Minangkabau karena patah hati karena tidak bisa menikah dengan gadis pujaannya, Zainab. Gadis pujaan Hamid itu hendak dikawinkan dengan kemenakan bapaknya. Maksud pernikahan itu agar harta warisan bapak Zainab bisa dijaga oleh kemenakannya sendiri, seperti yang terlihat dalam kutipan berikut.

"Segala kaum kerabat di darat telah ber-
mufakat dengan mamak hendak memper-
talikan Zainab dengan seorang kemenakan
almarhum bapakmu, yang ada di darat
itu. Dia sekarang sedang bersekolah di
Jawa. Maksud mereka hendak perkawinan
itu supaya harta benda almarhum bapak-
nya dapat dijagai oleh kaum keluarga
sendiri, oleh kemenakannya, sebab tidak
ada saudara Zainab yang lain, dia anak
tunggal.... (Hamka, 2010:35).

Berdasarkan kutipan di atas, dapat dipahami bahwa Hamid melakukan penentangan karena tidak setuju dengan sistem pernikahan menurut adat Minangkabau. Menurut adat Minangkabau, perkawinan yang paling ideal 
ialah perkawinan antara keluarga dekat, seperti perkawinan antara anak dengan kemenakan. Perkawinan demikian sering disebut dengan pulang ka mamak atau pulang ka bako. Pulang ka mamak berarti mengawini anak mamak, sedangkan pulang ka bako ialah mengawini kemenakan ayah. Dengan kata lain, perkawinan menurut adat Minangkabau ialah perkawinan "awak sama awak" (kita sama kita).

Pola perkawinan ideal menurut adat ini dilatarbelakangi oleh sistem komunal dan kolektivisme yang dianut oleh orang Minangkabau. Orang Minangkabau menganggap bahwa sistem yang mereka anut akan tetap terjaga dengan utuh kalau tidak dicampuri oleh orang luar (Navis, 1986:194). Bagi Hamid, pernikahan cara adat Minangkabau inilah yang tidak disukainya, sebab cara ini telah mengubur harapannya untuk menikah dengan Zainab. Padahal secara sosial, antara dia dan Zainab memiliki hubungan yang dekat. Bahkan, mereka saling mencintai. Namun, karena adat, Zainab harus menikah dengan laki-laki keponakan bapaknya yang belum tentu ia kenal secara dekat, sebab keponakan bapaknya itu sedang menempuh pendidikan di Jawa.

Menurut Navis (1999), banyak laki-laki Minangkabau bermigrasi ke bagian lain Indonesia ini karena kondisi-kondisi yang tidak memuaskan di kampung mereka, sebagai konsekuensi kekakuan sistem adat berkeluarga yang tidak mendukung penyelesaian bagi individuindividu yang telah mengendur ikatannya dengan tradisi. Merantau bagi orang Minangkabau merupakan konsekuensi dari sistem adat Minangkabau yang kaku. Seorang anak lakilaki yang sudah dewasa tidak diperbolehkan lagi tidur di rumah ibunya. Ia harus tidur di surau sampai ia menikah. Setelah menikah, ia tinggal di rumah istrinya. Jika istrinya ini banyak mempunyai saudara-saudara perempuan yang suami-suaminya bertempat tinggal pula di situ, tentulah tak heran bila sering terjadi persaingan-persaingan antara orangorang yang berpembayan itu. Hal ini ditambah pula dengan "pukulan" bagi si pemuda yang belum menikah tidak boleh tidur di rumah ibunya mendorong orang untuk pergi merantau ke daerah lain untuk mencari nafkah. Setelah ia bisa tegak, barulah pulang ke kampung dan sekalian mencari istri (induk nasi) bagi mereka yang belum menikah.

\section{Motif Penentangan Laki-laki Minangkabau Terhadap Budaya Minangkabau dalam Novel Hamka}

Pilihan Pandeka Sutan menetap di Mengkasar setelah selesai menjalani hukuman akibat membunuh mamaknya, Datuk Mantari Labih merupakan bentuk penentangannya terhadap budaya Minangkabau. Sebagai laki-laki Minangkabau, seharusnya Pandeka Sutan pulang ke kampungnya setelah selesai menjalankan hukumannya, sebab dalam pepatah Minangkabau sudah dikatakan: setinggi-tinggi terbang bangau, pulangnya ke kubangan jua. Sejauh apapun Pandeka Sutan meninggalkan Minangkabau, harus kembali ke kampung halaman.

Ungkapan dalam pepatah Minang itu tidak dihiraukan oleh Pandeka Sutan. Ia menganggap bahwa adat Minangkabau sudah memperlakukannya secara tidak adil. Setelah orang tuanya meninggal, harta pusaka peninggalan orang tuanya dijaga oleh Pandeka Sutan dan Mamaknya, Datuk Mantari Labih. Harta pusaka itu sudah seharusnya menjadi miliknya, sebab dia tidak mempunyai saudara perempuan. Namun, menurut adat Minangkabau harta pusaka harus jatuh kepada saudara perempuan, bila tidak ada perempuan kandung, maka harta itu jatuh ke saudara perempuan sepupu. Aturan adat inilah yang menghilangkan hak Pandeka Sutan untuk memiliki harta pusaka orang tuanya. Berbeda halnya dengan Datuk Mantari Labih, dia bisa menggadai harta pusaka kaumnya karena dia seorang penghulu. Meskipun menurut adat, siapapun tidak boleh menggadaikan harta pusaka, namun karena dia memiliki kekuasaan, kekuasaan itulah yang membuatnya bisa menggadaikan harta pusaka kaumnya. 
Seorang anak muda bergelar Pandeka Sutan, kemenakan Datuk Mantari Labih, adalah Pandekar Sutan kepala waris yang tunggal dari harta peninggalan ibunya, karena dia tak bersaudara perempuan. Menurut adat Minangkabau, amatlah malang seorang laki-laki jika tidak mempunyai saudara perempuan, yang akan menjagai harta benda, sawah yang berjenjang, Bandar buatan, lumbung berpereng, rumah nan gadang (Hamka, 2009:5-6).

Berdasarkan uraian di atas, terlihat bahwa begitu pentingnya saudara perempuan dalam adat Minangkabau untuk menjaga harta pusaka. Begitu juga keberadaan seorang mamak di Minangkabau berfungsi menjaga harta pusaka. Seperti yang dikemukakan oleh Amir (2007:84) bahwa mamak berkuasa kepada kemenakannya dan harta pusakanya, tetapi bukan untuk menghilangkan, melenyapkan, menjual, atau menggadaikannya dengan tidak sepakat dengan kemenakannya. Mamak berkuasa hanya atas pemeliharaan harta itu, supaya bertukuk (berkembang) dan bertambah. Di dalam petitih disebut jika hilang dicari, terbenam diselam, buruk diperbaiki, kecil diperbesar. Kemudian, mamak wajib menjaga dan memelihara malu, sopan, dan menunjuk, serta mengajari kemenakan. Namun, kekuasaan itu disalahgunakan oleh Datuk Mantari Labih, yaitu dengan menggadaikan harta pusaka kaumnya, sementara kemenakannya (Pandeka Sutan) dilarangnya menggadaikan harta pusaka.

...Berapa kali ia mencoba meminta supaya supaya dia diizinkan menggadai, bukan saja mamaknya yang menghalangi, bahkan pihak kemenakan-kemenakan yang jauh, terutama pihak yang perempuan sangat menghalangi, sebab harta itu sudah mesti jatuh ke tangan mereka, menurut hukum adat: "Nan sehasta, nan sejengkal, dan setampok sebuah jari" (Hamka, 2009:6).

Berdasarkan uraian di atas, dapat dipahami bahwa penentangan Pandeka Sutan ter- hadap budaya Minangkabau didasari oleh motif agama Islam. Menurut agama Islam antara anak perempuan dengan anak laki-laki memiliki hak yang sama untuk mendapatkan harta warisan. Islam tidak membedakan perempuan dengan laki-laki berdasarkan jenis kelamin dalam hal warisan. Oleh sebab itu, Pandeka Sutan merasa bahwa budaya Minangkabau sudah memperlakukannya secara tidak adil karena tidak mendapatkan hak atas harta warisan karena budaya Minangkabau menghendaki harta pusaka jatuh kepada saudara perempuan. Persoalan yang muncul bagi Pandeka Sutan adalah dia tidak mempunyai saudara perempuan sehingga harta pusaka keluarganya akan menjadi milik saudara perempuan sepupu. Aturan adat yang sangat bertentangan dengan Islam ini menyebabkan Pandeka Sutan memilih jalan tidak pulang ke Minangkabau.

Bila Pandeka Sutan (Tenggelamnya Kapal Van Der Wijck) memilih untuk tidak pulang ke Minangkabau, Hamid (Di bawah Lindungan $\left.K a^{\prime} b a h\right)$ memilih meninggalkan Minangkabau. Menurut Hamid, adat Minangkabau yang mengidealkan pernikahan antara anak dengan kemenakan telah memupuskan harapannya untuk memiliki Zainab, sebab keluarga ibu dan bapak Zainab lebih mengharapkan Zainab menikah dengan keponakan bapaknya supaya bisa menjaga harta pusaka peninggalan bapaknya.

\section{...Cuma saja saya mesti berikhtiar supaya luka-luka yang hebat itu jangan mendalam kembali, saya mesti berusaha, supaya ia berangsur sembuh. Untuk itu saya meng- ambil keputusan, saya mesti meninggal- kan kota Padang, terpaksa tak melihat wajah Zainab lagi, saya berjalan jauh (Hamka, 2010:40).}

Berdasarkan uraian di atas, dapat dipahami bahwa penentangan yang dilakukan oleh Hamid terhadap budaya Minangkabau didasari motif agama Islam. Menurut agama Islam, pernikahan yang terjadi antar seorang 
laki-laki dengan perempuan bukan berdasarkan hubungan keluarga, melainkan berdasarkan atas saling mencintai dan tidak melanggar syariat agama Islam. Oleh sebab itu, apa yang terjadi pada diri Zainab sangat tidak disenangi oleh Hamid sehingga ia memutuskan untuk meninggalkan Minangkabau dan memperdalam ilmu agamanya ke tanah Mekah.

\section{PENUTUP}

\section{Simpulan}

Berdasarkan uraian di atas, dapat dipahami bahwa novel karya Hamka sarat dengan pencerminan sosial budaya Minangkabau. Melalui karyanya, Hamka memprotes budayanya yang telah memperlakukan laki-laki secara tidak adil dengan cara menggambarkan posisi laki-laki Minangkabau yang dilematis, yaitu pada satu sisi laki-laki di Minangkabau bertugas menjaga harta pusaka, sementara pada sisi lain tidak mendapat bagian dari harta warisan itu. Kondisi ini memunculkan penentangan yang dilakukan laki-laki Minangkabau terimplimentasi dalam sikap tokoh laki-laki dalam cerita memilih hidup diluar Minangkabau daripada kembali ke Minangkabau, dan memilih meninggalkan Minangkabau daripada menetap di Minangkabau. Meskipun sikap ini terkesan sebagai sikap mengalah dan tidak berani melawan kenyataan, dengan cara itu tokoh cerita bisa membahagiakan dirinya, sekaligus juga untuk menunjukkan bahwa bukan hanya di Minangkabau saja mereka bisa hidup, tetapi di luar Minangkabau pun mereka bisa mendapatkan kehidupan lain. Motif yang mendasari penentangan laki-laki Minangkabau adalah motif agama Islam. Menurut agama Islam harta pusaka diwariskan kepada anak, bukan kepada kemenakan. Laki-laki dan perempuan memiliki hak yang sama dalam pembagian warisan. Begitu juga dalam menentukan pasangan hidup, dalam Islam tidak berdasarkan hubungan kekeluargaan, tetapi berdasarkan kepada saling mencintai dan tidak melanggar syariat agama Islam.

\section{Saran}

Berdasarkan simpulan penelitian, disarankan beberapa hal berikut. Pertama, diperlukan penelitian dengan menggunakan pendekatan dan teori sastra yang lain untuk mengungkap permasalahan lain yang terdapat dalam novel karya Hamka. Kedua, pengajaran sastra Indonesia, khususnya tentang karya sastra novel yang mengulas persoalan adat dan budaya masyarakat Indonesia perlu ditingkatkan dan disesuaikan dengan situasi sosial masyarakat baik di sekolah maupun di perguruan tinggi. Oleh karena itu, bahan-bahan bacaan novel, cerpen, dan puisi yang bertema tentang adat dan budaya masyarakat Indonesia sudah saatnya diberikan kepada peserta didik sebagai bahan ajar dalam pembelajaran sastra guna meningkatkan pendidikan budi pekerti peserta didik. Ketiga, dalam rangka meningkatkan pemahaman dan pengapresiasian karya sastra berupa novel diperlukan ketelatenan dan kesabaran dalam mengukuhkan dan manfsirkan nilai-nilai yang terkandung dalamnya, seperti adat dan budaya masyarakat Indonesia sebagai suatu keberagaman dalam rangka pendidikan multikultural.

\section{DAFTAR PUSTAKA}

Amir M.S. 2007. Adat Minangkabau: Pola dan Tujuan Hidup Orang Minang. Jakarta: Mutiara Sumber Widya.

Arifin, Zainal. 2009. "Dualitas Praktik Perkawinan Minangkabau" dalam Humaniora: Journal of Culture, Literature, Linguistics Volume 21. Nomor 2, Juni 2009. Yogyakarta: FIB UGM.

Arifin, Zainal. 2012. "Buru Babi: Politik Identitas Laki-laki Minangkabau" dalam Humaniora: Journal of Culture, Literature, Linguistics Volume 24. Nomor 1, Februari 2012. Yogyakarta: FIB UGM. 
Asri, Yasnur. 2011. “Analisis Sosiologis Cerpen "Si Padang" Karya Harris Effendi Thahar" dalam Humaniora: Journal of Culture, Literature, Linguistics Volume 23. Nomor 3, Februari 2011. Yogyakarta: FIB UGM.

Azwar, Welhendri. 2001. Matrilokal dan Status Perempuan dalam Tradisi Bajapuik. Yogyakarta: Galang Press.

Damono, Sapadi Djoko. 2002. Sosiologi sastra. Jakarta: Gramedia

Darma, Budi. 2007. Bahasa, Sastra, dan Budi Darma. Surabaya: JP Books.

Hamka. 2009. Tenggelamnya Kapal Van Der Wijk. Jakarta: Bulan Bintang.

Hamka. 2010. Di Bawah Lindungan Ka'bah. Jakarta: Bulan Bintang.

Hoggart, Richard. 1975. “Contemporary Cultural Studies: An Approach to the Study of Literature and society" in Malcolm Bradbury and David Palmer (ed.) Contemporary Criticsm. London: Edward Arnold.

Hudson, W.H. 1995. An Outline English Literature. London: G. Boll and Sons Ltd.

Jasril. 2015. “Nilai-nilai Pendidikan dalam Kaba Minangkabau" dalam Jurpipas Volume IV. Nomor 2, Desember 2015. Lubuk Alung: STKIP YDB Lubuk Alung.
Junus, Umar. 1986. Sosiologi sastra: Persoalan Teori dan Metode. Kuala Lumpur: Dewan Bahasa dan Pustaka.

Kleden, Leo. 1997. “Teks, Cerita, dan Transformasi Kreatif" dalam jurnal Kebudayaan Kalam Edisi X.

Navis, A.A. 1986. Alam Terkembang jadi Guru: Adat dan Kebudayaan Minangkabau. Jakarta: Grafiti Pers.

Navis, A.A. 1999. Yang Berjalan Sepanjang Jalan. Jakarta: Gramedia.

Ratna, Nyoman Kutha. 2004. Paradigm Sosiologi Sastra. Yogyakarta: Pustaka Pelajar.

Sairin, Sjafri. 2002. Perubahan Sosial Masyarakat Indonesia. Perspektif Antropologi. Yogyakarta: Pustaka Pelajar.

Thahar, Harris Effendi. 2002. "Pandangan Tokoh Laki-laki Terhadap Perempuan dalam Kaba dan Novel Indonesia Modern Berlatar Minangkabau: Suatu Analisis Perbandingan" dalam Humanus: Jurnal Imu-ilmu Humaniora Volume IV. Nomor 2, 2003. Padang: LPM Universitas Negeri Padang.

Valdes, Mario J. 1997. Phenomenology Hermeneutic and The Study of Literature. London: University of Toronto Press. 